\title{
論·文および 報 告
}

\section{再現溶接金属の連続泠却変態図*}

一再現溶接金属の連続冷却変態図の作成方法之二，三の溶接金属の連続冷却変態図一

$$
\begin{aligned}
& \text { 木原博** 鈴木 春義*** 稲 垣 道 夫*** } \\
& \text { 高木 乙麿****西茂**** 鈴木 和久**** 下山 仁一*** }
\end{aligned}
$$

\section{The Continuous Cooling Transformation Diagrams of Synthetic Weld Metals (SW-CCT Diagrams)*}

Zeit-Temperatur-Umwandlungs-Schaubild für kontinuierliche Abkühlung des künstlichen wiederproduzieren Sdhweissmetalls

$$
\text { - The Method of Plotting CCT Diagrams of Synthetic }
$$

Reproduced Weld Metals and Some SW-CCT Digrams-

Die Methode des Zeichens des TZU.Schaubildes für kontinuierliche Abkünstlichen wiederproduzieren Schweissmetalls und welche ZTU-Schaubild für kontinuierliche Abkühlung des küstlichen wiederproduzieren Schweissmetalle.

By Hiroshi Kihara** Haruyoshi Suzuki*** Michio Inagaki***

\section{Otomaro Takaki**** Shigeru Nishi**** KazuhisaSuzuki**** and Toshikazu Shimoyama****}

\section{Abstract}

This report describes the method of plotting tne continuous cooling transformation (CCT) diagram of weld metal, of which columnar structure and transformation on cooling are reproduced, and also describes the CCT diagrams of synthetic weld metals which contain $\mathrm{Si}$ and $\mathrm{Mn} ; \mathrm{Si}, \mathrm{Mn}$ and $\mathrm{Ni}$; and $\mathrm{Ni}, \mathrm{Cr}$ and $\mathrm{Mo}$. The results are follows.

1) The microstructure of actual weld metal can be reproduced by melting the center of the specimen $(4.5 \mathrm{~mm} \phi \times 70 \mathrm{mml})$ with induction heating. and CCT diagrams of synthetic weld metals can be plotted by this method.

2) The microstracture and hardness of synthetic weld metal are coincide with them of actual weld metal.

Der Umriß : Der Bericht beschreibt die Methoden des Zeichens des ZTU-Schaubildes für kontinuierliche Abkühlung des künstlichen wiederproduzieren Schwissmetalls, dessen Mikrostruktur und Umwandlung auf der Abkühlungen wewieder-produziert wird, und ouch beschreibt die ZTU-Schauild für kontinuierliche Abkühlung desküstlichen wieder produzieren Schwissmetalls, die enthalten Si und $\mathrm{Mn} ; \mathrm{Si} \mathrm{Mn}$ und $\mathrm{Ni}$; und auch $\mathrm{Ni}, \mathrm{Cr}$ and $\mathrm{Mo}$. Die Resultäter der Experimentes sind folgend.

(1) Die Mikrostruktur des tatsächlichen Schwissmetalls kan mit der Mitten der Prüflings (4.5 $\mathrm{mm} \phi \times 70 \mathrm{mml}) z u$ shmelzen durch die Hochfrequenzinduktionhitzen wiederproduziert werden, und die Umwandlung auf der Ackühlungen kan mit der Hitzanalysen gemessen werden.

Das ZTU-Schaubild für kontinuierliche Abkühlung des künstlichen wiederproduzieren Schweissmetalls kan mit der Methoden gezeicht werden.

(2) Und wir konnte tatsächlich gebeweiren, daß die Mikrostruktur und Härte des künstlichen wiederproduzieren Schweissmetalls haben die des tatsächlichen Schweissmetalls übereinstimmen.

\section{1.はしがき}

最近溶接構造用鋼材として強さ $60 \sim 90 \mathrm{~kg} / \mathrm{mm}^{2}$ の高 張力鋼が広範囲使用されようとしているが，溶接施工 にあたっては溶接熱影響部に関する硬化，じん性の低 下、拉よひワレが問題となり，これらの問題に対して は，鋼材の溶接用連続冷却変態図，溶接熱サイクル再現 試験、ワレ試験などの資料にもとずいて溶接入熱をコン トロールするととが必要である．溶接熱影響部を刘象と した鍋材の溶接用連続冷却変態図の作成については, 関

* 原稿受付 昭和38年 8 月28日（昭和37年度溶接学会春秋全国大会 (七て哭表)

** 正貝 東京大学工学部 Member, Tokyo University

***正員 合属材料技術研究所 Member, National Research Institute for Metals

***** 正員 新三贸更工KK神户造船所 Member, Kobe Shipyard and Engine Works, Mitsubishi Heavy Industries Reorganized Ltd.
口，稲垣による広範な研究があり，その方法が軟銅およ び高張力銅に応用されている．溶接金属についても母材 と同程度以上の強さとじん性を持たなければならないの で，高張力鋼の溶接金属では溶接金属自体を刘象とした 溶接入熱のコントロール，溶接金属の調質処理を考えな ければならないが，てれの基礎資料となるのは溶接金属 の連続冷却変態図（以下 CCT 図と云う）である.この 溶接金属の連続冷却変態図の作成にあたって問題となる 点は，鋼材を対象とした場合とことなり，実祭の溶接金 属に見られる柱状晶正再現しなければならないてとであ る、筆者らは，溶接金属の柱状昆を丸棒試験片に再現さ 世1)，溶接金属の颣固，冷却過程の変態と冷却後の組織 を再現し, 再現溶接金属連続冷却変態図 (以下SW-CCT 図しいう）を作成した。

本報告では再現溶接金属の CCT 図の作成方法と，そ 
れにもとづき，軟鋼および $50 \sim 60 \mathrm{~kg} / \mathrm{mm}^{2}$ 高張力鋼を 対象とした Si-Mn 系 $\mathrm{CO}_{2}$ アーク溶接金属, 低温用鋼材 を対象とした $\mathrm{Ni}$ 系 $\mathrm{CO}_{2}$ アーク溶接金属, $70 \sim 80 \mathrm{~kg}$ / $\mathrm{mm}^{2}$ 調質高張力鋼と HY 80 鋼を対象とした $\mathrm{Ni}-\mathrm{Cr}-\mathrm{Mo}$ 系 $\mathrm{CO}_{2}$ アーク溶接金属について再現溶接金属の連続冷 却変態図 (CCT 図) を作成した結果を報告する.

\section{2. 再現溶接金属連続冷却変態図 (SW-CCT 図) の作成方法}

実際の溶融溶接における溶接金属の成形過程を簡単に 述べる, 溶接金属部は溶融温度以上の高温に急熱さ れ，その高温にほとんぞ保持されるととなく急冷され る. 凝固過程においては溶接金属と母材との境界部（ポ ンド）より疑固が始まり，ほぼ熱流と反対方向に凝固が 進行する．鋳造組織には柱状晶と粒状晶があるが, 溶接 金属の場合, 凝固過程におりる温度勾配がきわめて大き いので, ボンドにほほ直角に大きな柱状晶が発達し中央 部では, 柱状晶がやや上向きになり溶接金属の表面近く で若干の粒状晶が観察されるのが普通である，凝固後に おける冷却過程においてはデルタフェライト，オーステ ナイトに変態し, さらに温度が低下すると, オーステ ナイトから, 冷却速度に応じて, フェライト, パーライ ト, 中間段階組織, マルテンサイトのうちのいずれかの 組織へと変態する.

一般の溶接金属に見られる初析フェライトの方向性は 柱状晶に起因するあのであり，溶接金属を丸棒試験片に 再現するにはまず柱状晶を再現しなければならないが， そのためには, 前述のごとく, 試片を溶融状態から楚固 させ, その凝固過程において大きな温度勾配を与えてや らなければならない.オーステナイからフェライト,パ ーライト, 中間段階組織, マルテンサイト組織への変態 温度の測定には武片を溶融する関係から, 膨張により測 定するととが実験上きわめて困難であり, 試片の冷却曲 線より温度一冷却速度曲線を描いて決定するいわゆる熱 分析法があっとも便利な方法であると考えられる. これ らの諸点を考慮して溶接金属を再現させるための試片 の溶融および冷却要領を Fig. 1 亿, 試片の寸法形状を Fig. 2 亿示す. 試片の溶融方法は, 高周波誘導加熱法に より行なう. 加熱コイルは 1 ターンまたは 2 ターンコイ ルを使用し, 試片の中央長さ約 5 15 mm の部分を約 $10 \mathrm{sec}$ 以内に溶融するととができる. 使用した高周波加 熱装置の出内は $15 \mathrm{KW}$, 発振周波数は $70 \mathrm{KC}$ である. 溶融した金属は, 外側の石英管によって保護される.こ の石英管の内径は $4.6 \sim 4.7 \mathrm{~mm} \phi$ が適当であり, これよ りあ内径が小さいと加熱中の試片によりワレることがあ る. Photo. 1 に試片をセットした状態を示す. 試片は

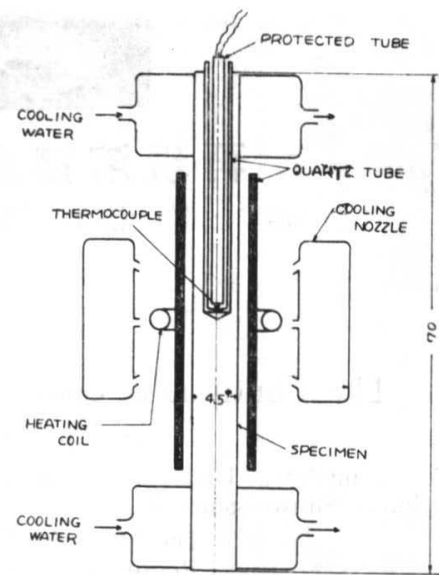

Fig. 1 Melting and cooling method of the specimen

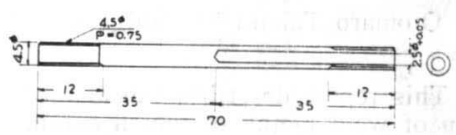

Fig. 2 Details of the specimen

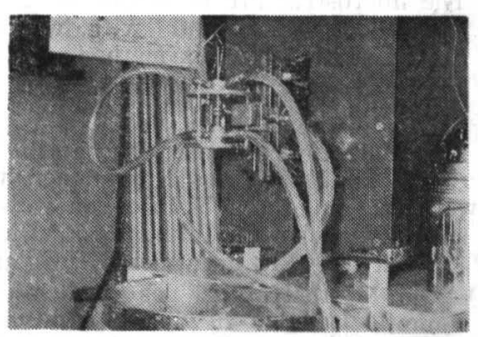

Photo. 1 Melting apparatus of the specimen

Fig. 2 のように直径 $4.5 \mathrm{~mm}$ 長さ $70 \mathrm{~mm}$ で両側にネジ 部を設け片側から $2.5 \mathrm{~mm} \phi$ の穴を中央部まであけてあ る. この穴に温度測定のため Pt-PtRh (13\%) $0.2 \mathrm{~mm} \phi$ の熱電対をそう入した. この際 Fig. 1 に示すでとく溶 融した金属から熱電対を保護する石英管は, 試片の中心 にあけられた穴との間に, できるだけ空気が入らぬよう に注意した. 熱電刘は溶接点を通して, ペン書き $\mathrm{X}-\mathrm{Y}$ 記録計に接続され，温度一時間曲線を自記させた．この

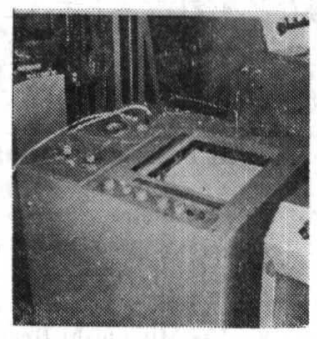

Photo. 2 X-Y recorder 
ペン書き $\mathrm{X}-\mathrm{Y}$ 記録計は, 縦軸に温度 $0 \sim 1500^{\circ} \mathrm{C}$, 横軸 が時間で横軸全長 $250 \mathrm{~mm}$ を $4 \mathrm{sec} \sim 30 \mathrm{~min}$ の広範囲 に送り速度が変えられるようになっている．とのペン書 き $\mathrm{X}-\mathrm{Y}$ 记録計の外観写真を Photo. 2 亿示す.

このようにして試片の中央部を高周波誘導加熱方法で 短時間内に溶融し, 両端部に熱が流れるようにして溶融 部が凝固する時に大きな温度勾配を与えることができ る. そのときの溶融金属の凝固過程は, 溶融部の両端か ら凝固が始まり, 中央部に向って凝固が進み柱状晶が形 成されるのである.

この方法による再現溶接金属の顕微鏡 組 織 と実際の $\mathrm{CO}_{2}$ アーク溶接による溶接金属の顕微鏡組織とを Photo. 3 に示す. この再現溶接金属は実際の $\mathrm{CO}_{2}$ アーク溶接 金属より Fig. 2 亿示した試片を採取し, 溶接金属を再 現したあのであり，両者はきわめて一致していることが わかり, このような方法により, 溶接金属の柱状晶が再 現できるのである.

Photo. 4 に $\mathrm{CO}_{2}$ アーク溶接の再現溶接金属の溶接端 部加ら, 中央部に向って進む柱状晶の連続顕微鏡組織を 示す. 中央部付近においては, 両端から凝固が進んでき て, 最終に凝固する位置であり, この部分は同時に凝固 すると考えられ，方向性ある組織がなくなり等方状の結 晶となっている.

試片の中央部を溶融するととにより，実際の溶接金属 の組織を再現することができるが, 凝固における冷却の 状況は図に示す冷却ノズルより石英管外倒から $\mathrm{N}_{2}$ ガス を吹きつけて強制冷却を行ない, 試片の溶融部の冷却を

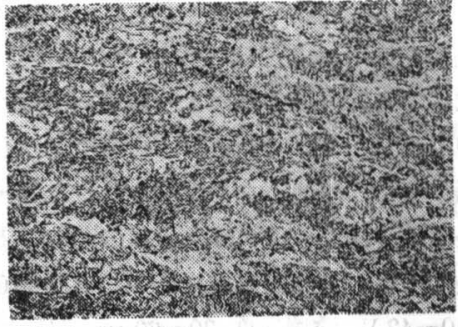

(a) Synthetic weld metal

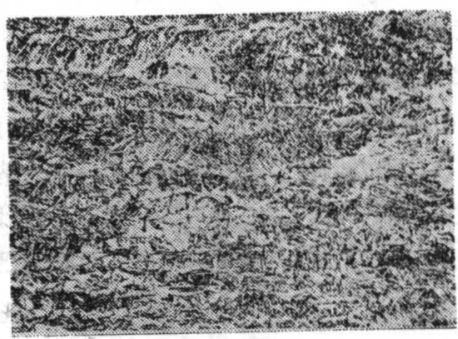

(b) $\mathrm{CO}_{2}$ arc weld metal

Photo. 3 Microstructure of synthetic weld metal and actual $\mathrm{CO}_{2}$ arc weld metal (C 0.09, Si 0.45, Mn 0.87) $\times 100\left(\frac{53}{100}\right)$

調整するととができる. 本実験における試片の冷却方法 は, 熱伝達と強制冷却を混合したものであり, 実際の溶 接の場合の溶接金属の泠却は, ほとんど熱伝達による冷 却と考えられる:ので， $\mathrm{CO}_{2}$ アーク溶接の場合に例をと り, 本実験における試片の冷却曲線と比較する.

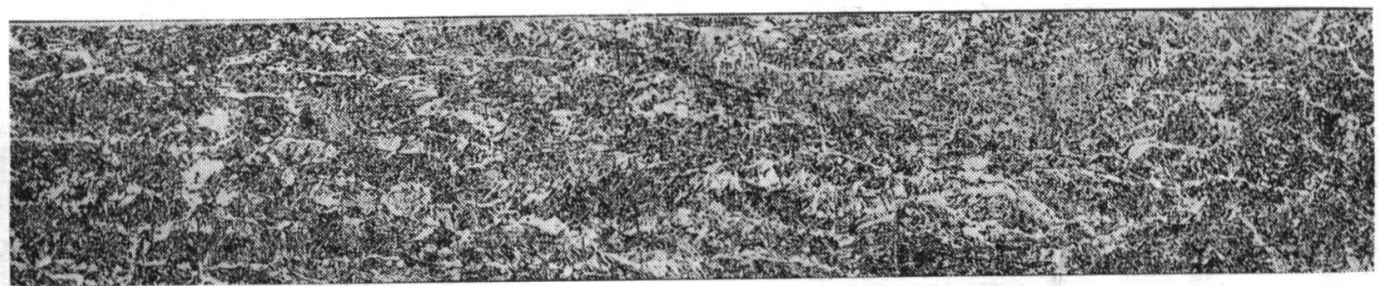

$\stackrel{\uparrow}{\text { Bond }} \leftarrow$ Melting part

(1) Bond part

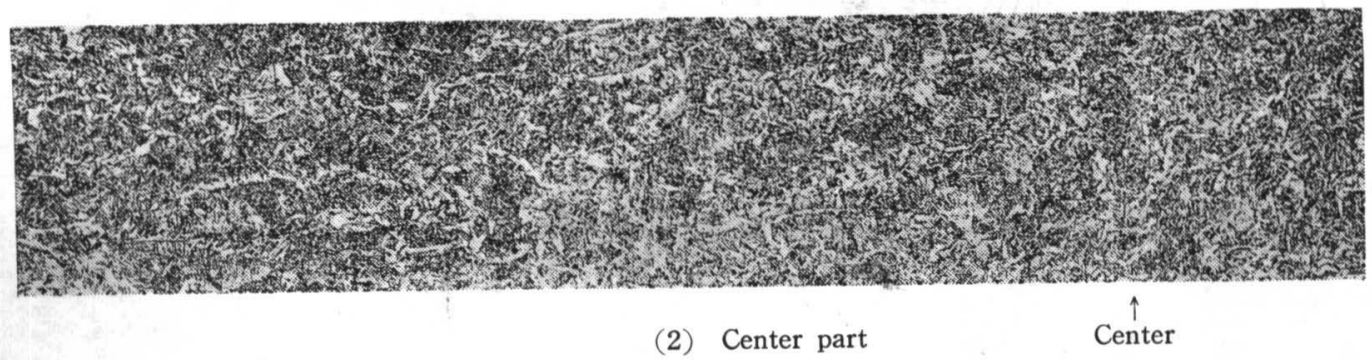

Photo. 4 Continuous microstructure of synthetic weld metal $(\times 100) \times \frac{50}{100}$ 
$\mathrm{CO}_{2}$ アーク溶接の熱サイクル測定は，アルメルークロ メル熱電対を使用し，電磁オシログラフにより行なった。 測定位置については板の裹面より熱電対をそう入し，溶 接金属中の熱サイクルの測定は不可能であるから, 中央 直下のボンド部の熱サイクルを測定した。測定したとき の溶接条件は，鋼線 $2.0 \mathrm{~mm} \phi$ 使用の上きの実用上の適 正溶接条件と思われる溶接電流 (D.C) $500 \sim 700 \mathrm{~A}, \boldsymbol{T}$ ク電压 $40 \sim 42 \mathrm{~V}$, 溶接速度 $30 \sim 60 \mathrm{~cm} / \mathrm{min}$ の範囲の 5 種類の溶接入熱で，板厚 $30 \mathrm{~mm}$ にビードをおいたとき のものである.Fig. 3 に测定した熱サイクルを示す.

Fig. 4 に本実験における溶融金属部の熱サイクルを示 す. 図中の線 1 3 は $\mathrm{N}_{2}$ による強制冷却を行なわない 場合であり，その場合の冷却曲線の相違は，溶融部の長 さをかえて調整したすのである。曲線 4，5は $\mathrm{N}_{2}$ によ り強制冷却したもので，曲線の下に示す数值は $\mathrm{N}_{2}$ の圧
力 $\left(\mathrm{kg} / \mathrm{cm}^{2}\right)$ である. 曲線 6 は永冷したものである.

鉄鋼材料の変態状況におよぼす要因としては，オース テナイト結晶粒度， $\mathrm{A}_{3}$ 変態点加らの泠却状況などであ る. Fig. 3 と Fig. 4 とを比較すると $1500^{\circ} \mathrm{C}$ 加ら約 $800^{\circ} \mathrm{C}$ までの冷却時間は短時間でほとんど無視してもよ $く, A_{3}$ 変態点からの冷却状況が連続冷却変態の本質か らいって大きな要素であるから $800^{\circ} \mathrm{C}$ を0秒としたと きの両者の冷却曲線を描くと Fig. 5 および Fig. 6 の ようになる．Fig. 5 峙間を等目盛にとったものであ り，Fig. 6 は対数目盛によったものである. Fig. 5 お よび Fig. 6 において，実際の溶接金属の冷却曲線亡， 本実験の再現溶接金属の泠却曲線とを比較すると，再現 溶接金属は強制冷却を伴うので，約 $500^{\circ} \mathrm{C}$ 以下に拉り る冷却がはやいが, $800^{\circ} \mathrm{C} \sim 500^{\circ} \mathrm{C}$ まではほぼ類似の冷 却曲線を示す. 連続冷却変態では $800^{\circ} \mathrm{C}$ 加ら $500^{\circ} \mathrm{C}$

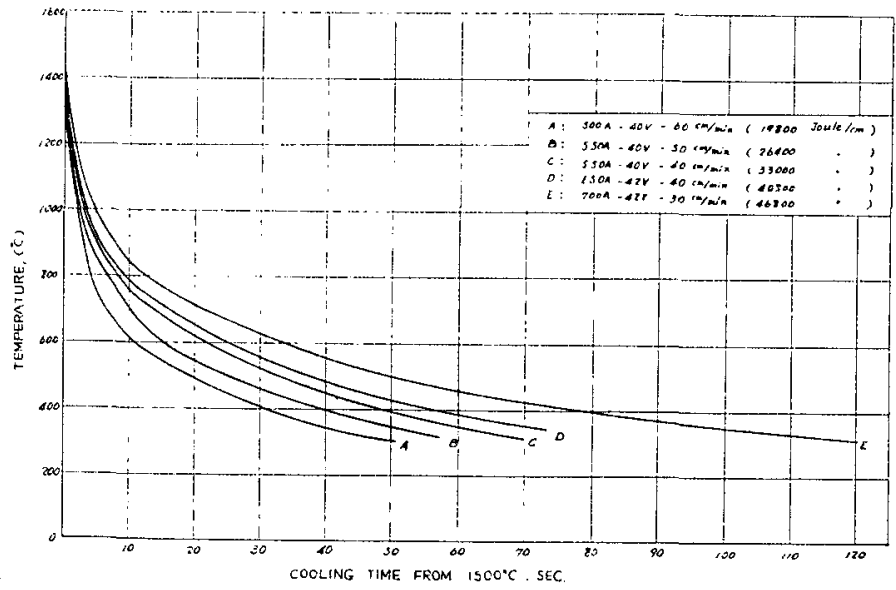

Fig. 3 Cooling curves of $\mathrm{CO}_{2}$ arc weld metals deposited on steel plates; thickness $30 \mathrm{~mm}$

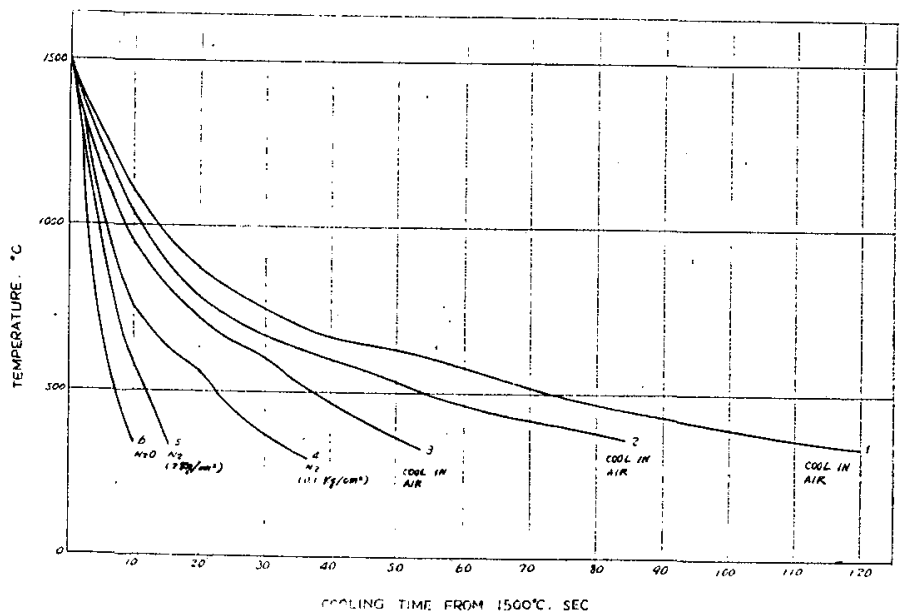

Fig. 4 Cooling curves of synthetic weld metals 


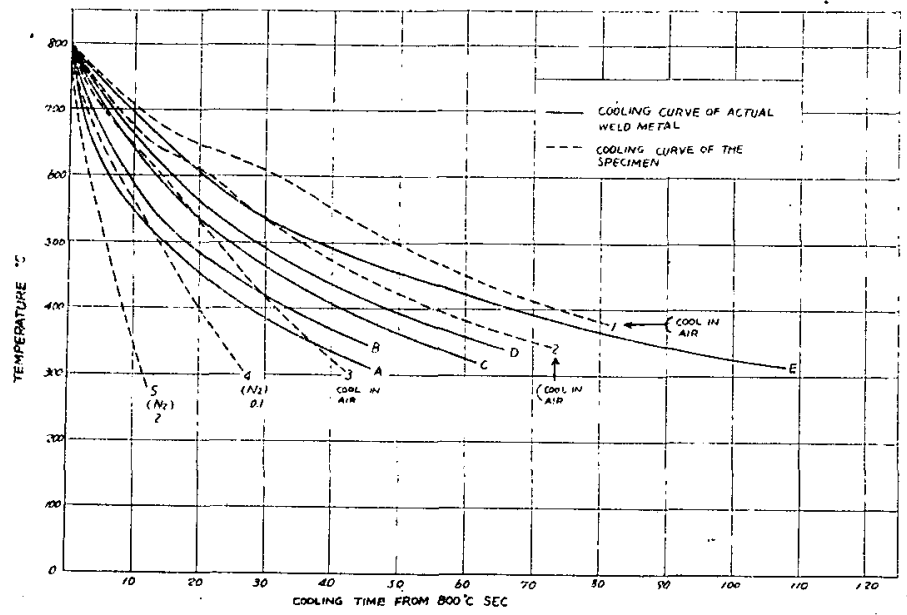

Fig. 5 Cooling curves from $800^{\circ} \mathrm{C}$ of actual weld metals and synthetic weld metals

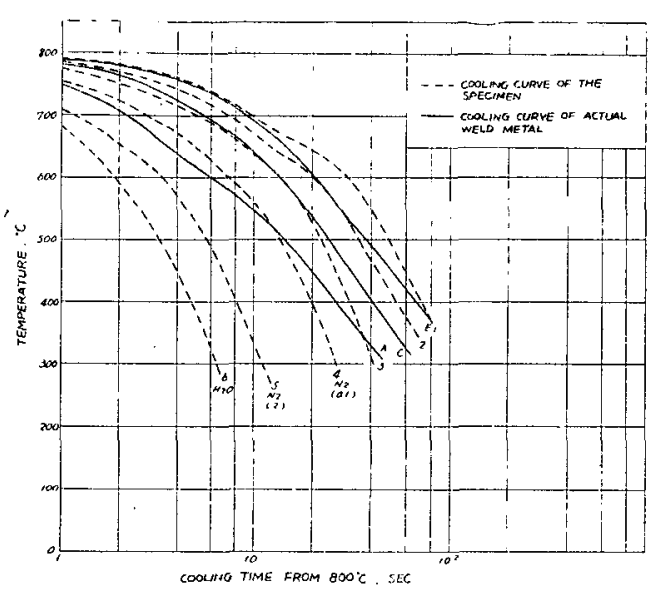

Fig. 6 Cooling curves from $800^{\circ} \mathrm{C}$ of actual weld metals and synthetic weld metal

での冷却時間がオーステナイトからの変態状況に大きな 影響をおよぼすので，本実験の再現溶接金属は実際の溶 接金属のときとほとんど同じ変態を示すと考えられる.

再現溶接金属の $800^{\circ} \mathrm{C}$ 加ら $500^{\circ} \mathrm{C}$ までの冷却時間の 調整筙囲は， Fig. 21 亿示す試片を用いた場合，Fig. 5 および Fig. 6 からわかるように約 3 50 sec である. 被覆了ーク溶接で板厚 $20 \mathrm{~mm}$ に標準溶接条件 $(170 \mathrm{~A}$ $24 \mathrm{~V}-15 \mathrm{~cm} / \mathrm{min}$ ) でビードを㧅いたきの $800^{\circ} \mathrm{C}$ から $500^{\circ} \mathrm{C}$ までの冷却時間が約 $6 \mathrm{sec}$ であり， $\mathrm{CO}_{2}$ アーク溶 接では, 板厚 $30 \mathrm{~mm}$, 溶接入熱 $19800 \mathrm{Joule} / \mathrm{cm} \sim 46800$ $\mathrm{Joule} / \mathrm{cm}$ の䈖囲では約 15 40 sec であり，本実験の再 現溶接金属の冷却時間筙囲にはいる。サブマージドアー ク溶接の場合屯著しく溶接入熱が大きい場合を除いてと の笵囲に入る上考元られる。
以上 SW-CCT 四の作成のための実験方法についての べたが，乙れは，被覆アーク溶接， $\mathrm{CO}_{2}$ アーク溶接など の溶融溶接の溶接金属にも適用できる.

\section{3．供試溶接金属の SW-CCT 図}

鋼板上に $\mathrm{CO}_{2}$ アーク溶接法によって Table 1 亿示す 化学成分の溶接金属を溶着し，Fig. 2 に示した丸棒の 試験片を探取し実験に供した。

Table 1 Chemical compositions of weld metals

\begin{tabular}{c|c|c|c|c|c|c|c}
\hline Remarks & type & $\mathrm{C}$ & $\mathrm{Si}$ & $\mathrm{Mn}$ & $\mathrm{Ni}$ & $\mathrm{Cr}$ & $\mathrm{Mo}$ \\
\hline $\mathrm{A}$ & $\mathrm{Si}-\mathrm{Mn}$ & 0.09 & 0.45 & 0.87 & - & - & - \\
$\mathrm{B}$ & $\mathrm{Ni}$ & 0.09 & 0.31 & 0.95 & 1.72 & - & - \\
$\mathrm{C}$ & $\mathrm{Ni}-\mathrm{Cr}-\mathrm{Mo}$ & 0.09 & 0.32 & 0.92 & 2.09 & 0.85 & 0.35 \\
\hline
\end{tabular}

\subsection{Si-Mn 系溶接金属 “A” の SW-CCT 图}

試片を 2 でのべたような要領で高周波誘導加熱力法に より, 試片の中央部を溶础 (約 $1600^{\circ} \mathrm{C}$ ) し, 種々の冷却 方法で齿固冷却させた。，その連続冷却曲線をペン書き $\mathrm{X}-\mathrm{Y}$ に記録させ，それより温度一冷却速度曲線から冷 却中における変態温度を測定した。

変態温度の測定の一例をのべる. 試料 2 (放冷) の疑 固冷却の温度時間曲線を Fig. 7 に示す. その曲線より 温度冷却速度曲線を求め, 試料の湿徽鏡組織よりフェラ イト，パーライトおよび少量の中間段階組織から構成さ

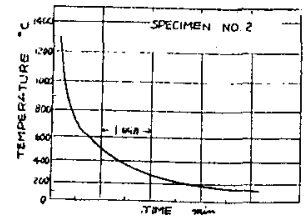

Fig. 7 Cooling curve of the specimen no. 2 
れているので，各々の組織の変態温度を温度一冷却曲線 より求めると, オーステナイトからフェライトへの変態 開始温度は， $725^{\circ} \mathrm{C}$. 同じく中間段階組織への䇅態開始 温度は， $565^{\circ} \mathrm{C}$ である. これらの変態開始温度を，温度 一冷却速度曲線上に示すと Fig. 8 のようになる。

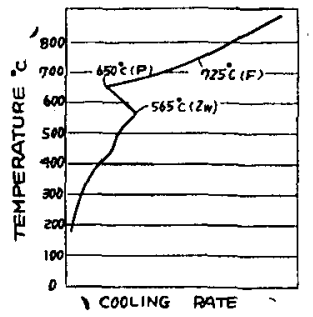

Fig. 8 Relation between temperature and cooling rate of the specimen no. 2

このようにして，種々の冷却方法で冷却させた試片の 温度一時間曲線上り温度一冷却速度曲線を求め，これか ら切り出した試片につき顕微鏡組織を調べフェライト， パーライト, 中間段階組織, およびマルテンサイト組織 への变態開始温度を求めた. 各試料について，Y軸に等 目盛で冷却途中の温度 $\left({ }^{\circ} \mathrm{C}\right)$ をとり，X軸に冷却途上に おける， $800^{\circ} \mathrm{C}$ を 0 秒として対数目盛で時間 $(\mathrm{sec})$ を とって冷却曲線をえがき，その曲線上に各組織の変態温 度をプロットして CCT 図を作るよ Fig. 9 のようにな る.なお CCT 図については，変態の本質から $A_{\mathbf{s}}$ 変態 点を $0 \mathrm{sec}$ として描くのが通常であるが溶接諸条件との 関係を求め, 溶接金属の組織, 力タサ, 变態領域を推定 するために，本報告では，便宜上 $800^{\circ} \mathrm{C}$ を $0 \mathrm{sec}$ とし て CCT 図を作成した。
Fig. 9.中の冷却曲線1～3は放冷, 放冷曲線 4〜6は $N$ ガスによる強制冷却, 冷却曲線 7 は水冷の場合であり, 各冷却曲線の下に示す数値は，ビッカースカタサ（荷重 $10 \mathrm{~kg}$ ）の测定值である. 破線で示した冷却曲線 $1^{\prime} \sim 3^{\prime}$ は冷却が著しくはやい場合であり，試片の中央部を溶融 し，溶接金属を再現して行なうことができないので，補 足的に小試片 $(6 \mathrm{~mm} \phi \times 1.5 \mathrm{~mm})$ を使い, 最高加熱温度 $1350^{\circ} \mathrm{C}$ からの泠却により熱分析法で変態点を测定した すのである. Fig. 9 中の A は, 再現溶接金属がオース テナイト組織である領域， F はオーステナイトからフ ライトが生じる変態領域， $\mathrm{P}$ は同じくパーライトが生じ る領域，Zw は同じく中間段階組織が生しる変態領域を 示す.この図よりパーライトが生じる臨界冷却曲線は試 料 6 の冷却曲線に一致し，その時の $800^{\circ} \mathrm{C}$ 加 $500^{\circ} \mathrm{C}$ までの臨界冷却時間 $C_{p}^{\prime}$ は $6 \mathrm{sec}$ であり，それに相当 するビッカースカタサ（荷重 $10 \mathrm{~kg}$ ） は HV 257 であ る.

Fig. 10 亿再現溶接金属の $800^{\circ} \mathrm{C}$ から $500^{\circ} \mathrm{C}$ までの 冷却時間とビッカースカタサとの関係を示す. Photo. 5

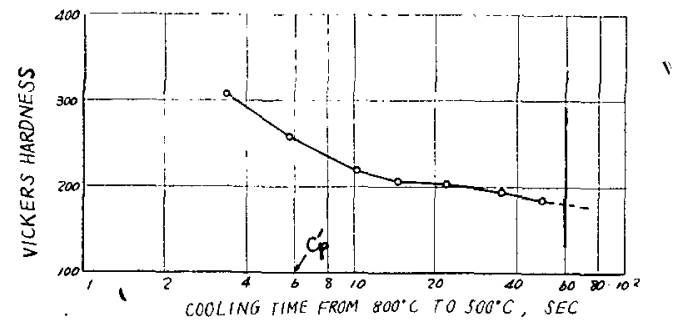

Fig. 10 Relation between hardness and cooling time from $800^{\circ} \mathrm{C}$ to $500^{\circ} \mathrm{C}$ of weld metal "A" (Si-Mn type)

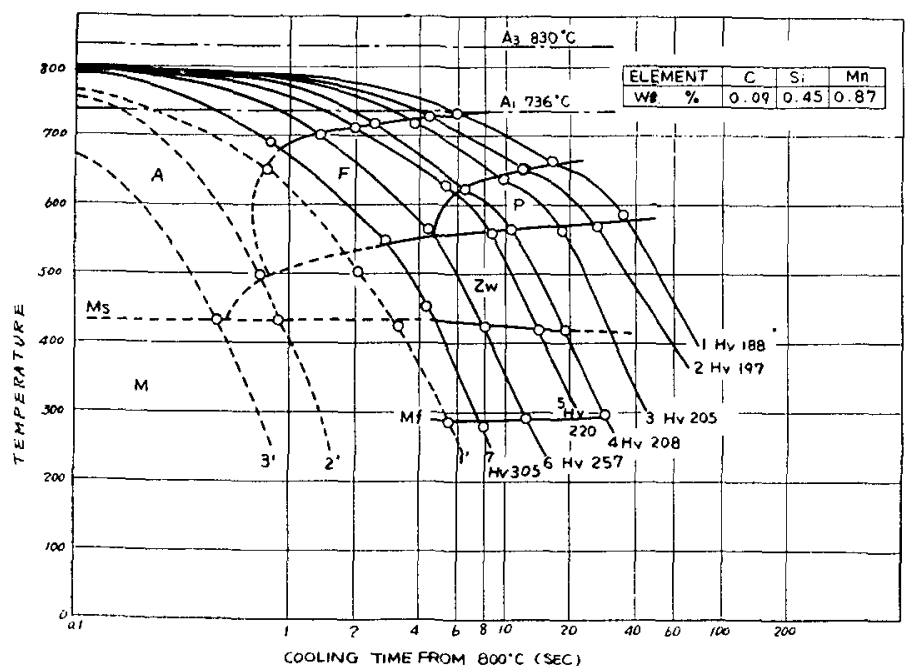

Fig. I SW-CCT diagram of weld metal "A" (Si-Mn tyre) 


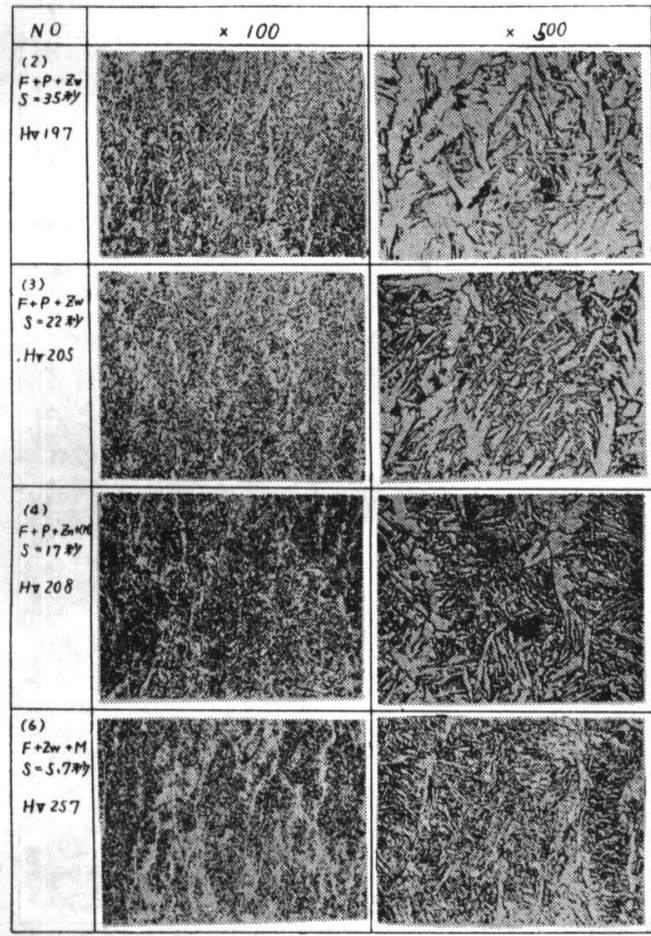

Photo. 5 Microstructure of synthetic weld metal "A" (Si-Mn type)

の横に組織の構成, $800^{\circ} \mathrm{C}$ から $500^{\circ} \mathrm{C}$ までの冷却時間 S,ビッカースカタサを示した. 各試料の低倍率 $(\times 100)$ の顕微鏡組織加実際の溶接金属に見られる方向性ある 組織が観察され, 溶接金属を再現していることがわか る. 高倍率 $(\times 500)$ の顕微鏡組織加 , 冷却が遅い試料 2 では著しく発達したフェライト，パーライトと極く少 量の中間段階組織からなる．冷却がはやくなるにしたが って,フェライトの結晶粒が小さくなり, 試料 4 では中 間段階組織がはっきり之観察され，また極く少量のマル テンサイト組織も存在する.ささらに冷却がはやくなり試 料 5 になるとマルテンサイト組織がやや多くなり, 試料 6 になると中間段階組織とマルテンサイト組織が多く, パーライトが存在しなくなる.

つぎに実際の $\mathrm{Si}-\mathrm{Mn}$ 系 $\mathrm{CO}_{2}$ ガスシールドアーク溶接 の溶接金属と再現溶接金属とを比較するために, 再現溶 接金属の試片を採取したときと同様に，キルド鋼（板厚
$20 \mathrm{~mm}$, 幅 $150 \mathrm{~mm}$, 長さ $250 \mathrm{~mm}$ ) 上の中央に, 溶接電 流, (D.C) $600 \mathrm{~A}$, アーク電圧 $42 \mathrm{~V}$, 溶接速度 $20,40,60$, $80,100 \mathrm{~cm} / \mathrm{min}$ でビードを扤き, 中央部よりビードに 直角方向にカタサ測定の試片を採取し, 溶接金属部につ いて，6〜8点のビッカースカタサ（荷重 $10 \mathrm{~kg}$ ）を測 定した.な抢各溶接条件で, アルメルークロメル熱電対 を使い, 電礎オシログラフにより熱サイクルを測定し, $800^{\circ} \mathrm{C}$ から $500^{\circ} \mathrm{C}$ までの冷却時間を実測した. これら の結果をまとめたあのを Table 2 亿示す. との結果を Fig. 10 の再現溶接金属の $800^{\circ} \mathrm{C}$ から $500^{\circ} \mathrm{C}$ までの冷 却時間とビッカースカタサ（荷重 $10 \mathrm{~kg}$ ) との関係を比 較する之, Fig. 11 のようになる。この図よりわかるよ

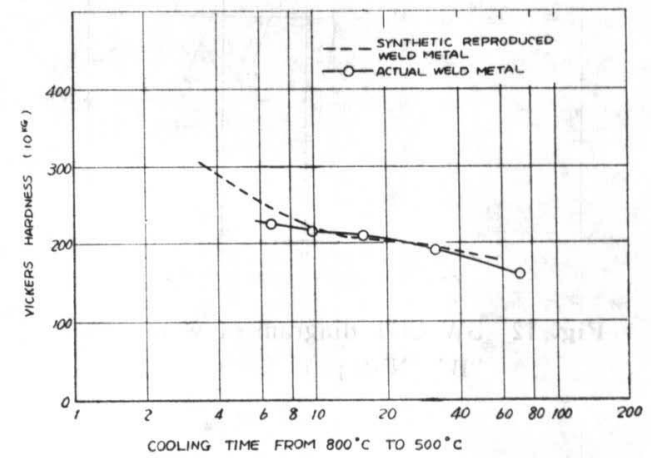

Fig. 11 Comparison of synthetic reproduced weld metal and actual weld metal

うに，実際の溶接金属と再現溶接金属は，きわめてよく 一致した傾向を示した．とのととは，本実験のような方 法で溶接金属を再現し, SW-CCT 図を作成するととによ り, 実際の溶接金属の冷却中におりる変態と, 冷却後に おける組織およびカタサなどの諸性を推定できるととを 立証するあのである.

\section{$3.2 \mathrm{Ni}$ 系溶接金属 “B” $の \mathrm{SW}$-CCT 図}

同様な方法で溶接金属 $\mathrm{B}(\mathrm{Ni}$ 系，化学成分は Table 1 参照）の SW-CCT 図を作成すると Fig. 12 のようにな る. 図中にパーライトが生じる臨界冷却曲線を破線で示 した. との曲線からパーライトが生じはじめるときの $800^{\circ} \mathrm{C}$ から $500^{\circ} \mathrm{C}$ までの臨界冷却時間 $C_{p}^{\prime}$ を求めると $19 \mathrm{sec}$ になる. Fig. 13 に $800^{\circ} \mathrm{C}$ から $500^{\circ} \mathrm{C}$ までの冷

Table 2 Welding conditions and hardness of actual $\mathrm{CO}_{2}$ arc weld metal

\begin{tabular}{|c|c|c|c|c|c|c|c|}
\hline No & $\begin{array}{c}\text { Plate } \\
\text { thickness } \\
(\mathrm{mm})\end{array}$ & $\begin{array}{l}\text { Welding } \\
\text { current } \\
\text { (Amp) }\end{array}$ & $\begin{array}{c}\text { Arc voltage } \\
\text { (Volt) }\end{array}$ & $\begin{array}{l}\text { Welding } \\
\text { speed } \\
(\mathrm{cm} / \mathrm{min})\end{array}$ & $\begin{array}{c}\text { Cooling time } \\
\text { from } 800^{\circ} \mathrm{C} \text { to } 500^{\circ} \mathrm{C} \\
\text { (sec) }\end{array}$ & $\mathbf{H V}_{\mathrm{V}}$ & $(10 \mathrm{~kg})$ \\
\hline 1 & 20 & 600 & 40 & 25 & 71 & & 160 \\
\hline 2 & 20 & 600 & 42 & 40 & 32 & & 192 \\
\hline 3 & 20 & 600 & 42 & 60 & 16 & & 211 \\
\hline 4 & 20 & 600 & 42 & 80 & 98 & & 216 \\
\hline 5 & 20 & 600 & 42 & 100 & 67 & & 226 \\
\hline
\end{tabular}




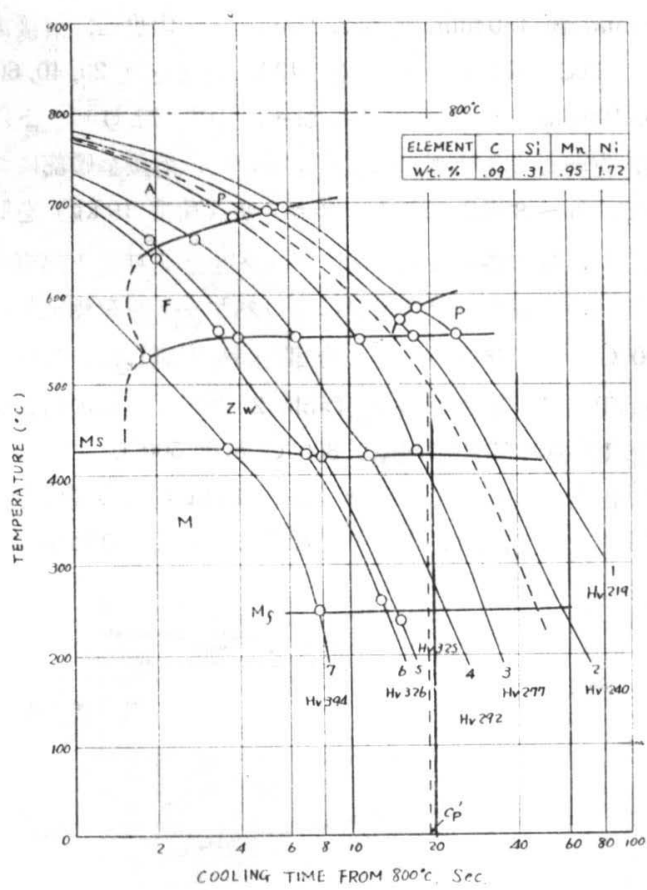

Fig. 12 SW-CCT diagram of weld metal "B" (Ni-type)

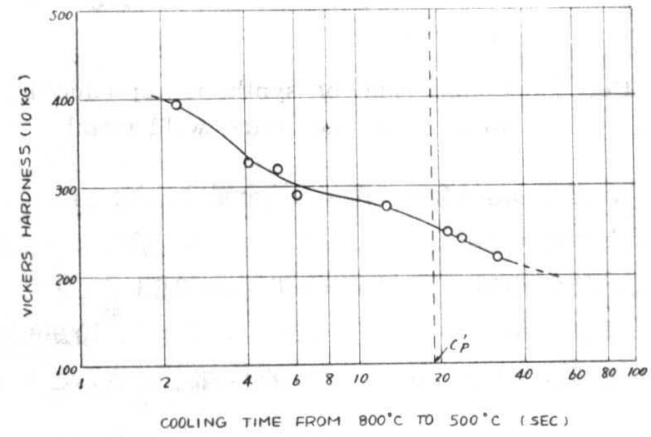

Fig. 13 Relation between hardness and cooling time from $800^{\circ} \mathrm{C}$ to $500^{\circ} \mathrm{C}$ of weld metal "B" (Ni type)

却時間とビッカースカタサ（荷重 $10 \mathrm{~kg}$ ）との関係を示 す. この図より $C_{p}^{\prime}$ に相当するビッカースカタサは, HV 256 である. Photo. 6 に Ni 系 $\mathrm{CO}_{2}$ シールドアー ク溶接の再現溶接金属の代表的な顕微鏡組織を示す. 低 倍率 $(\times 100)$ の顕微鏡組織では, 実際の溶接金属と同様 な方向性ある組織が再現されていることがわかる. 高倍 率 $(\times 500)$ の顕微鏡組織については, 試料 1 ではフェラ イト, パーライトおよび中間段階組織であるが, 冷却が はやくなり試料 2 では, マルテンサイト組織が観察され る.さらに冷却がはやくなり試料 5 になるとフェライト が著しく減少し, パーライトがなくなり, 中間段階組織 とマルテンサイト組織が大部分をしめるようになる.

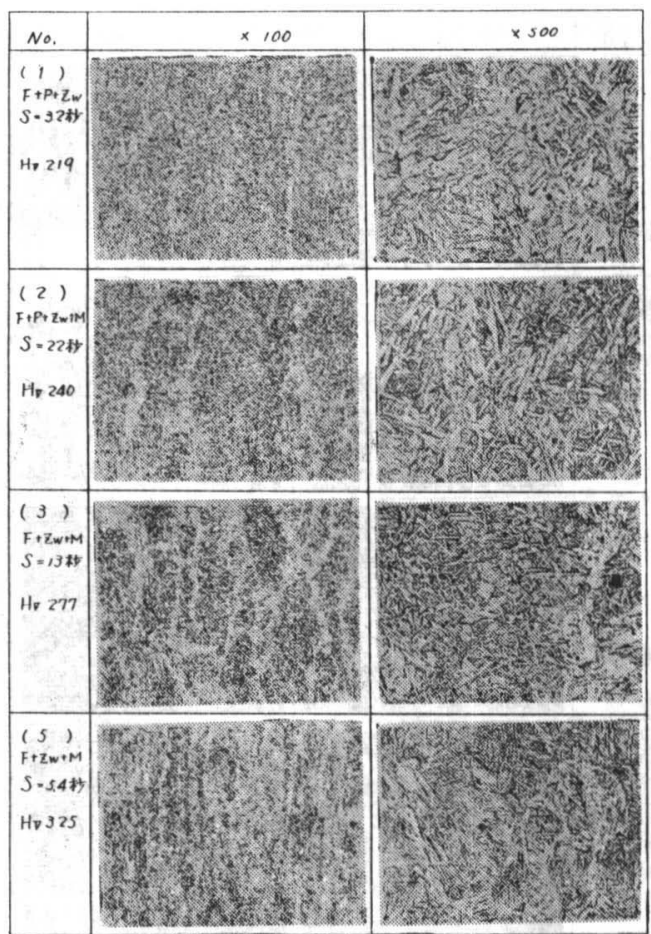

Photo. 6 Microstructure of synthetic weld metal "B" (Ni type)

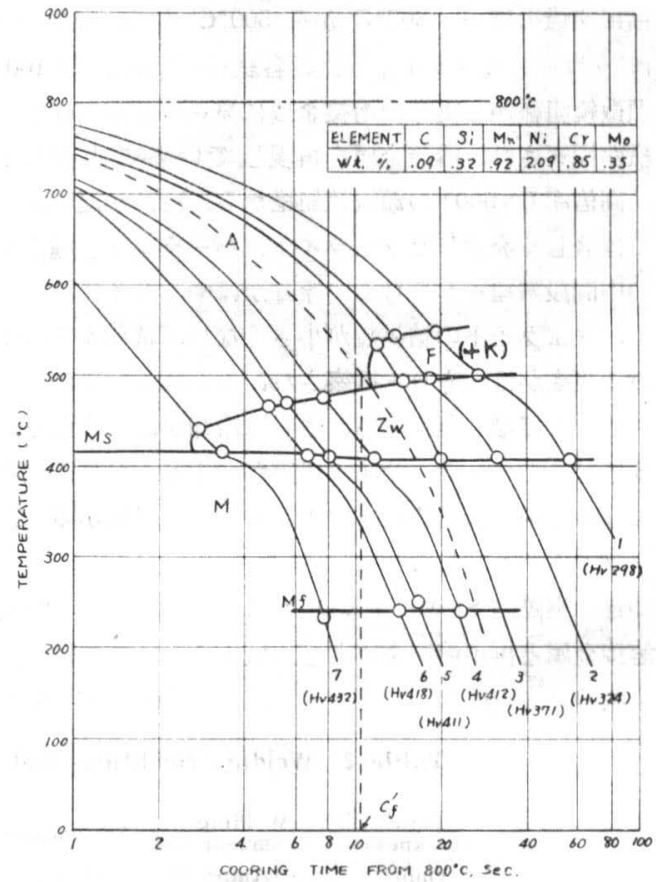

Fig. 14 SW-CCT Diagram of synthetic peproduced weld metal "C" (Ni-Cr-Mo)

$3.3 \mathrm{Ni}-\mathrm{Cr}-\mathrm{Mo}$ 系溶接金属 “C” 同じく溶接金属 C (Ni-Cr-Mo 系, 化学成分は Table 


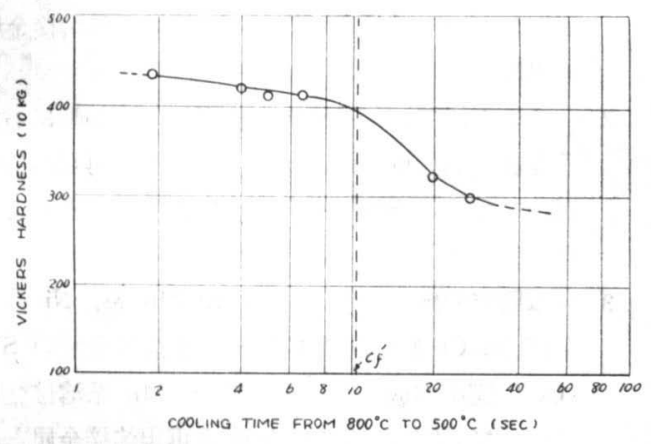

Fig. 15 Relation between hardness and cooling time from $800^{\circ} \mathrm{C}$ to $500^{\circ} \mathrm{C}$ of synthetic weld metal "C" ( $\mathrm{Ni}-\mathrm{Cr}-\mathrm{Mo}$ type)

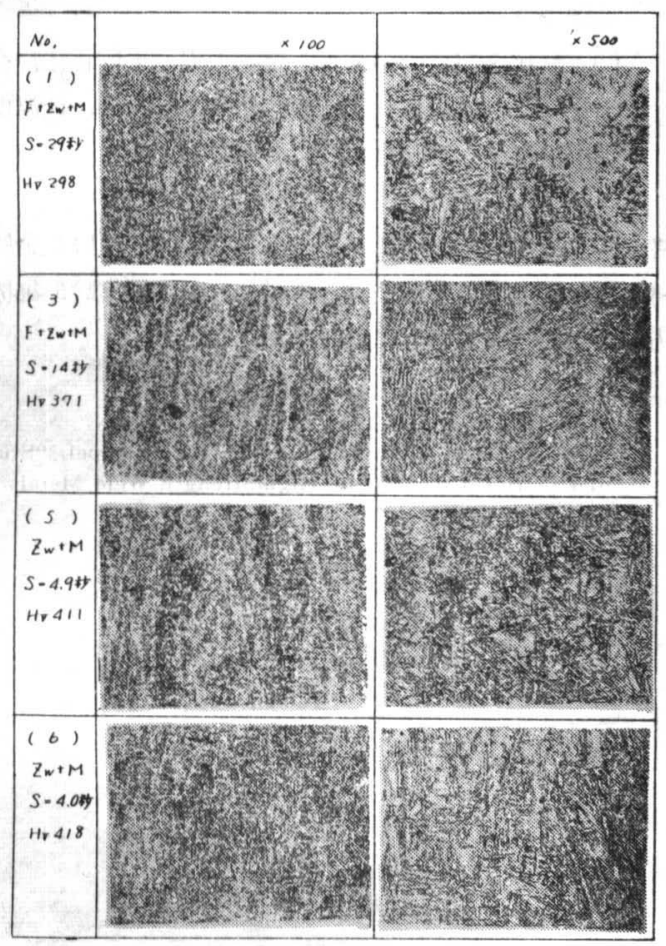

Photo. 7 Microstructure of synthetic weld metal "C" (Ni-Cr-Mo type)

1 参照）の SW-CCT 図を作成すると Fig. 14 のように なる. 図中にフェライト (十炭化物 K) が生じる臨界冷 却曲線 $\mathrm{K}$ を破線で示した。 これによりフェライト（十炭 化物 K）が生じるための $800^{\circ} \mathrm{C}$ から $500^{\circ} \mathrm{C}$ までの臨界 冷却時間 $C_{f}{ }^{\prime}$ は $10.5 \mathrm{sec}$ である. Fig. 15 に $800^{\circ} \mathrm{C}$ か ら $500^{\circ} \mathrm{C}$ までの泠却時間とビッカースカタサ（荷重 10 $\mathrm{kg}$ ）との関係を示す．との図より $C_{f^{\prime}}$ に相当するビッ カースカタサは $\mathrm{HV} 396$ である. Photo. 7 K, Ni-CrMo 系 $\mathrm{CO}_{2}$ ガスシールドアーク溶接の再現溶接金属の 顕微鏡組織を示す. 低倍率 $(\times 100)$ の顕微鏡組織に上れ
ば, 結晶の方向性が再現されているととがわかる，高倍 率 $(\times 500)$ の顕微鏡組織によると, 武料 1 ではパーライ 卜は全くなくなり,フェライト（十炭化物 $\mathrm{K} ）$ ，中間段 階組織とマルテンサイト組織よりなるが, 冷却がはやく なり試料 3 になるとフェライトがきわめて少なくなり, ほとんど中間段階組織とマルテンサイト組織よりなる. さらに冷却が早い試料 5,6 では, 中間段階組織が著し く隇少し, 大部分マルテンサイト組織よりなりビッカー スカタサは HV 400 以上になる.

\section{4. 三種類の SW-CCT 図の比較}

溶接金属 A. B. C. の SW-CCT 困を合せて描くと Fig. 16 のようになる. 四中の冷却曲線 (A), () は Fig. 6

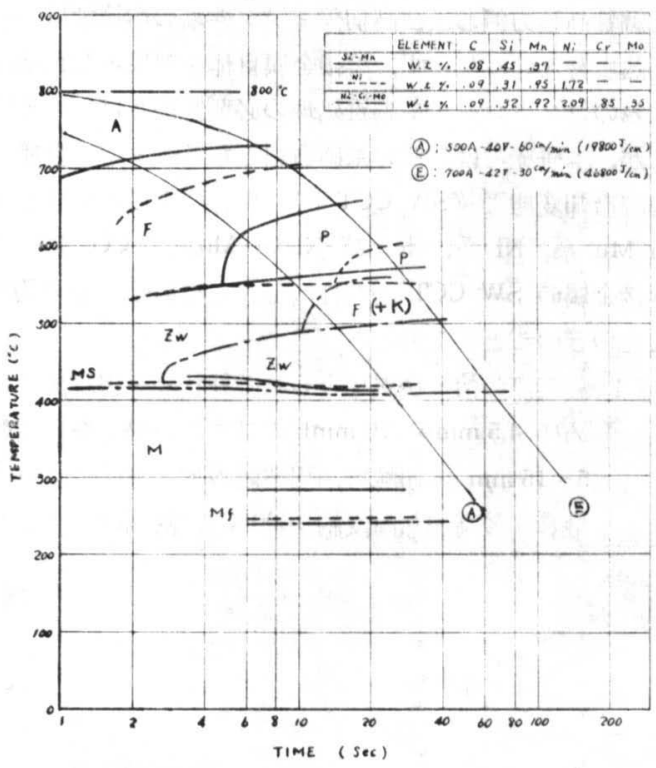

Fig. 16 Comparison of $\mathrm{Si}-\mathrm{Mn}, \mathrm{Ni}, \mathrm{Ni}-\mathrm{Cr}-\mathrm{Mo}$ type SW-CCT diagrams

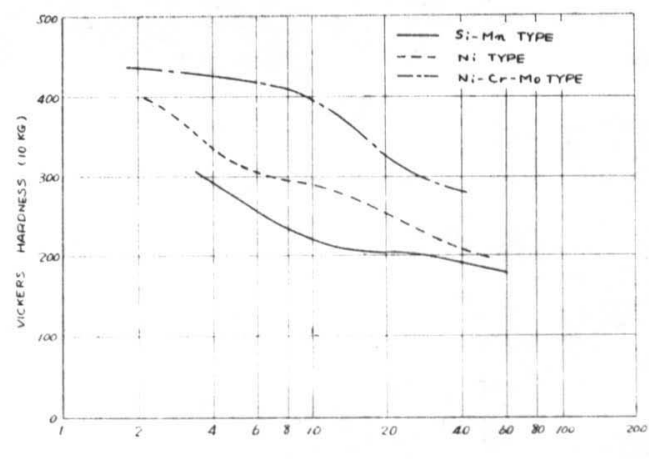

COOLING TIME FROM $800^{\circ} \mathrm{C}$ TO $500^{\circ} \mathrm{C}$ (SeC)

Fig. 17 Relation between hardness and cooling time from $800^{\circ} \mathrm{C}$ to $500^{\circ} \mathrm{C}$ of $\mathrm{Si}-\mathrm{Mn}$, $\mathrm{Ni}, \mathrm{Ni}-\mathrm{Cr}-\mathrm{Mo}$ type synthetic weld metals 
そ示した実際の溶接の場合の椧却曲線であり，(Aは溶接 入熱 $19800 \mathrm{Joule} / \mathrm{cm}$, ()は同しくく, $46800 \mathrm{Joule} / \mathrm{cm} の$ 場合である. Fig. 17 に Fig. 10,13 および 15 に示した 再現溶接金属 $800^{\circ} \mathrm{C}$ から $500^{\circ} \mathrm{C}$ までの冷却時間とビッ カースカタサ（荷重 $10 \mathrm{~kg}$ ）との関係を示した。 Fig. 16 によると溶接金属に合金元素の添加量加增加すると変態 領域が右に移動し，フェライトと中間段階組織が出始め る温度が低下する．との傾向は溶接金属中に $\mathrm{Cr}, \mathrm{Mo}$ が 添加されると著しくなるととがわかる. Fig. 17 によれ ば，溶接金属中の合金元素と溶接金属の硬化性の傾向が わかる， $\mathrm{Cr}, \mathrm{Mo}$ は溶接金属を著しく硬化させる.

\section{5.むすび}

祮質高張力鋼および高切久きジン性鋼の溶接では，溶 接熱影響部のみならず，溶接金属自体を対象とした溶接 入熱のコントロールや調質処理の必要性がさけばれてい るが，本研究では，その基礎資料となるべき溶接金属の 連続冷却変態図（SW-CCT 図）の作成方法を確立し, $\mathrm{Si}-\mathrm{Mn}$ 系, $\mathrm{Ni}$ 系, および $\mathrm{Ni}-\mathrm{Cr}-\mathrm{Mo}$ 系の $\mathrm{CO}_{2}$ アーク 溶接金属の SW-CCT 図を作成した。そその結果を要約す るとつぎのでとくである.

（1）実際の溶接金属にみられる柱状晶を再胃するた めに $4.5 \mathrm{~mm} \phi \times 70 \mathrm{mml}$ の試片の中央部を長さ約 5 15 mm の領域を高周波誘導加熱方法に上り溶 融し（最高加熱温度約 $1600^{\circ} \mathrm{C}$ ), 凝固時に大きな
温度勾配を与えることによって，完全に溶接金属 の組織を再現することができた。

（2）乙の方法で，溶接金属を再現し，冷却時におけ る変態を熱分析方法によって测定し，再現溶接金 属のいわゆる SW-CCT 図を作成することができ た.

(3) 本研究で確立した方法で, $\mathrm{Si}-\mathrm{Mn}$ 亲, $\mathrm{Ni}$ 系お よび $\mathrm{Ni}-\mathrm{Cr}-\mathrm{Mo}$ 系の $\mathrm{CO}_{2}$ アーク溶接金属の SW -CCT 図を作成した. そして Si-Mn 系溶接金属 について，実際の溶接全属亡再現溶接金属との $800^{\circ} \mathrm{C}$ から $500^{\circ} \mathrm{C}$ までの冷却時間とカタサを比 較した結果，きわわてよく一致した傾向を示し， ほぼ完全に，溶接金属の変態を再現したことが確 認できた。

（4）溶接金属についても，鋼材の場合と同様に，合 金元素が添加されると変態領域が長時間, 低温度 側に移動し，硬化することがわかった。

終りにのぞみ，本研究にいろいろ御支嗳いただいた金属 材料技術研究所，宇田技官，中村技官および実験御協 力いただいた大野悟君に梁く感謝する.

\section{参考文 献}

1) H.W. Mishler, R.E. Monrue and P.J. Rieppel. "Studies of Hot Cracking in High-Strength Weld Metals." W.J., Vol. 40 (1961) No. 1 is 